\title{
Impressions from EASD 2018
}

\author{
Dr Caroline Day reports from the European Association for the Study of \\ Diabetes 54th annual meeting in Berlin, Germany, 1-5 October 2018
}

\section{Introduction}

The 2018 EASD meeting, held at the Messe Berlin Exhibition Halls in Berlin-Charlottenburg - a short rail journey from the city centre - was the largest EASD since 2014, with 15,699 on-site delegates from 32 countries. Nevertheless, there were 2,428 fewer delegates than when the meeting was last held here in 2012. However, there were more than 10,000 online participants at this meeting. This year almost $20 \%$ of on-site delegates came from the nine countries that border Germany, and the host nation provided most delegates. The UK fell into third place this year with 980 delegates, being usurped by the USA, which was represented by just over $6 \%$ of delegates.

\section{Abstracts and access}

There were 48 fewer abstracts for presentation at this meeting than last year. This year abstracts 1-264 were presented in 48 oral sessions and abstracts 265-1218 were presented across six poster events. Abstracts and electronic posters can be viewed via the EASD virtual meeting, and abstracts can also be accessed via the meeting app (downloadable from Google play and the App store) and in the EASD journal Diabetologia - available free as a pdf.1,2 Efficient use of the virtual meeting can be facilitated by viewing the programme-at-aglance webpage to check out the EASD study groups and non-commercial satellite symposia as well as the scientific programme sessions. ${ }^{3}$ Some oral presentations (OP) and symposia (S) are noted below. The industry-sponsored symposia, meet-theexpert sessions and their programmes are listed online (scroll down the page). ${ }^{4}$ Several of the EASD live TV interviews can be seen on YouTube. Many presentations were accompanied by simultaneous full publication online; where possible, full publications are cited herein.

\section{SGLT inhibition}

Sodium glucose co-transporter (SGLT) inhibitors received extensive attention at the meeting (eg, OP13, OP19, S17, S21, S25, S26), and a special issue of Diabetologia
Table 1 Award lectures at EASD 2018

\begin{tabular}{|c|c|c|}
\hline Prize & Lecturer & $\begin{array}{l}\text { Title (day of presentation) and link to } \\
\text { EASD interview }\end{array}$ \\
\hline $\begin{array}{l}\text { 50th Claude } \\
\text { Bernard Lecture }\end{array}$ & $\begin{array}{l}\text { Jaakko Tuomilehto } \\
\text { (Finland, Kuwait) }\end{array}$ & $\begin{array}{l}\text { Prevention of type } 2 \text { diabetes: the dream that } \\
\text { came true }\end{array}$ \\
\hline $\begin{array}{l}\text { 33rd Camillo } \\
\text { Golgi Lecture }\end{array}$ & $\begin{array}{l}\text { Peter P Nawrot } \\
\text { (Heidelberg, Germany) }\end{array}$ & $\begin{array}{l}\text { Diabetic complications - an alternative } \\
\text { view on diabetes }\end{array}$ \\
\hline $\begin{array}{l}\text { 12th Albert } \\
\text { Renold Lecture }\end{array}$ & $\begin{array}{l}\text { Rohit N Kulkarni } \\
\text { (Boston, USA) }\end{array}$ & $\begin{array}{l}\text { Epitranscriptomics (RNA methylation): a new } \\
\text { level of regulation in islet biology and } \\
\text { metabolism }\end{array}$ \\
\hline $\begin{array}{l}\text { 4th EASD-Novo } \\
\text { Nordisk } \\
\text { Foundation } \\
\text { Diabetes Prize } \\
\text { for Excellence }\end{array}$ & $\begin{array}{l}\text { Gokhan S Hotamisligil } \\
\text { (Boston, USA) }\end{array}$ & A quarter century of immunometabolism \\
\hline $\begin{array}{l}\text { 53rd Minkowski } \\
\text { Lecture }\end{array}$ & $\begin{array}{l}\text { Fredrik Bäckhed } \\
\text { (Gothenburg, Sweden) }\end{array}$ & $\begin{array}{l}\text { The gut microbiota - a forgotten organ - } \\
\text { that contributes to glucose metabolism } \\
\text { (see Virtual Meeting, Thursday) } \\
\text { https://www.youtube.com/watch?v=QvRdGj931xM }\end{array}$ \\
\hline
\end{tabular}

was printed to accompany the meeting - a notable feature is a paucity of European authors. ${ }^{5}$ Amongst the presentations this year, particular attention was given to the potential use of SGLT inhibitors as adjuncts to insulin in type 1 diabetes. In the phase 3 EASE-2 and EASE-3 trials, overweight adults with type 1 diabetes (>1 year; eGFR >30 $\mathrm{mL} / \mathrm{min} / 1.73 \mathrm{~m}^{2}$ ) were given empagliflozin $10 \mathrm{mg}$ or $25 \mathrm{mg}$ as an adjunct to insulin, and in EASE-3 patients were also assigned to empaglifozin $2.5 \mathrm{mg}$ plus intensified insulin therapy (\$26). The primary endpoints were assessed at week 26 in both studies and, in EASE-2 patients, were additionally followed to week 52. Empagliflozin decreased $\mathrm{HbA}_{1 \mathrm{c}}$, body weight, insulin dose and systolic blood pressure (consistent with previous studies in which SGLT inhibitors were added to insulin-treated type 2 patients). Continuous glucose monitoring (CGM) showed that patients spent more time in target glucose range. Genital infections were commoner in empagliflozin treated patients. Severe hypoglycaemia was rare and diabetic ketoacidosis (DKA) occurred more with empagliflozin $25 \mathrm{mg}$ and $10 \mathrm{mg}$, but was similar between empagliflozin $2.5 \mathrm{mg}$ and placebo. ${ }^{6}$

The oral dual SGLT1 and SGLT2 inhibitor sotagliflozin is in clinical development. In the European inTandem2 study, addition of sotagliflozin $200 \mathrm{mg}$ or $400 \mathrm{mg}$ as an adjunct to optimised insulin therapy in adults with type 1 diabetes (>1 year; eGFR >45 $\mathrm{mL} / \mathrm{min} / 1.73 \mathrm{~m}^{2}$ ) for 52 weeks decreased $\mathrm{HbA}_{1 \mathrm{c}}$, body weight and insulin dose and increased time in target glucose range. Diarrhoea and genital infections were commoner with sotagliflozin, but there were fewer episodes of documented and severe hypoglycaemia in people taking sotagliflozin, although there were more cases of DKA ( 3\%) compared with placebo. ${ }^{7}$

A secondary analysis of data from the CANVAS programme showed reductions in $\mathrm{HbA}_{1 c}$ progressively diminished with declining renal function, but the relative effects of canagliflozin on body weight and most cardiovascular (CV) and renal outcomes were similar across the eGFR subgroups. ${ }^{8}$

The CVD-REAL session (S25) highlighted comparative effectiveness of SGLT2 inhibitors on CV outcomes and the utility of 


\begin{tabular}{ll} 
Trial abbreviations & \\
\hline EASE & Empagliflozin as adjunctive to insulin therapy in type 1 diabetes \\
\hline ELIXA & $\begin{array}{l}\text { Evaluation of cardiovascular outcomes in patients with type } 2 \text { diabetes } \\
\text { after acute coronary syndrome during treatment with AVE0010 } \\
\text { (Lixisenatide) }\end{array}$ \\
\hline EXSCEL & EXenatide Study of Cardiovascular Event Lowering \\
\hline CANVAS & CANagliflozin cardioVascular Assessment Study \\
\hline CARMELINA & $\begin{array}{l}\text { Cardiovascular and Renal Microvascular outcome study with LINAgliptin } \\
\text { in patients with type 2 diabetes mellitus }\end{array}$ \\
\hline HARMONY & Albiglutide QW cardiovascular outcome trial \\
\hline LEADER & $\begin{array}{l}\text { Liraglutide Effect and Action in Diabetes: Evaluation of } \\
\text { cardiovascular outcome Results }\end{array}$ \\
\hline PIONEER & Oral semaglutide trial \\
\hline RISE & Restoring Insulin Secretion \\
\hline
\end{tabular}

real-world evidence. The OBSERVE-4D study, a retrospective real-world analysis across four databases (>720,000 new users of glucose lowering agents), showed that the SGLT2 inhibitors conferred a similarly reduced risk of hospitalisation for heart failure, including patients with established CV disease. There was no evidence of increased risk of lower limb amputations with canagliflozin compared with other SGLT2 inhibitors and non-SGLT2 inhibitors in the overall population and in those with established CV disease. ${ }^{9}$

\section{Incretin action}

Among reports of cardiovascular outcome trial (CVOT) data, the HARMONY study (S04) with albiglutide (a once-weekly injectable glucagon-like peptide-1 receptor agonist (GLP-1RA)) showed superiority to usual care $(p=0.0006)$, reducing major adverse cardiovascular events (MACE) by $22 \%$. Adverse events were similar in both groups. ${ }^{10}$ In June 2018, marketing of albiglutide was discontinued for commercial reasons, but it is possible that another company will consider returning it to the European market.

Several presentations described further analyses from CVOTs including ELIXA, ${ }^{11}$ EXSCEL and LEADER (eg, OP07, OP13, S17). The session on the PIONEER programme (S19) showed that, at 26 weeks, once-daily oral semaglutide (titrated to $3 \mathrm{mg}, 7 \mathrm{mg}$ or $14 \mathrm{mg}$ ) as monotherapy or as combination therapy reduced $\mathrm{HbA}_{1 \mathrm{c}}$ and body weight more effectively than comparator treat- ments and was as effective as the injection. Adverse events were consistent with those shown with injected semaglutide.

Glucose-dependent insulinotropic polypeptide (GIP) acts on the beta cell to potentiate nutrient-induced insulin secretion offering a novel therapeutic approach. The concept of 'twincretins' (combination of GIP and a GLP-1RA), supported by a phase 2 trial, was considered in S53 and other novel combinations were presented in OP28. ${ }^{12}$

CARMELINA is the latest CVOT with a dipeptidyl peptidase-4 (DPP4) inhibitor to report (S35). Like the other DPP4 inhibitors, linagliptin was non-inferior to standard treatment with regard to MACE and renal outcomes, although a relatively high proportion (62\%) of patients had renal disease (eGFR $<60 \mathrm{~mL} / \mathrm{min} / 1.73 \mathrm{~m}^{2}$ ). Linagliptin had neutral effects on hospitalisation for heart failure and adverse events were consistent with those known for the class.

\section{Symposia etc}

The invited symposium to reprise the UKPDS (S15) set the scene leading to Professor Robert Turner designing the UKPDS (his widow Dr Jenny Turner was a guest of EASD at the symposium), highlighted the cumulative observations which occurred during the 20 years (1977-1997) of this study there were five simultaneous publications when the study reported at EASD 1998 and considered the impact of this study which sought to assess policy rather than individual drugs (of which five new classes have become available in the UK since the
UKPDS reported). The UKPDS is the only large trial of newly diagnosed type 2 diabetes. It addressed the issue of early glycaemic control (additionally vindicated by the post-trial follow-up data) and is the evidential cornerstone of clinical practice in the first years of treatment. The international impact of UKPDS is apparent throughout the EASD meeting and is manifest in the ADA-EASD consensus guidance - the most recent version of which was presented on the last morning of the meeting (S41). ${ }^{13}$

The CV safety of the serotonin 2C receptor agonist lorcaserin in overweight/ obese people with or at high CV risk was investigated in the CVOT CAMELLIA (S33). This appetite suppressant improved weight loss (vs diet/lifestyle) and did not increase MACE. ${ }^{14}$ Lorcaserin-induced weight loss decreased incident diabetes, improved glycaemic control and some patients achieved remission of diabetes. ${ }^{15}$ Lorcaserin is available in the USA, but has not been approved in Europe.

The RISE study is investigating a range of interventions to determine their impact on the preservation or improvement of beta-cell function in youths and adults with pre-diabetes or early type 2 diabetes. In a dedicated session (SO9) it was concluded that weight loss may be an effective way to reduce the severe insulin resistance of puberty. ${ }^{16}$ Adults treated for 2 years with metformin or adjustable gastric band (LapBand $^{\circledR}$ ) achieved a $1.7 \mathrm{~kg}$ and $10.6 \mathrm{~kg}$ weight loss, respectively, but there were no significant differences between the treatments for indices of glycaemic control, despite gastric banding improving the acute beta-cell response to glucose. ${ }^{17}$

Technological advances continue apace in glucose monitoring and insulin delivery, including closed-loop systems and their utility, as well as studies on beta-cell replacement (eg, OP10, OP15, OP18, S24). ${ }^{18}$

\section{Advocacy}

The St Vincent Declaration was launched in 1989 as an initiative to set targets at a national level to aid healthcare systems to improve outcomes for people with diabetes. ${ }^{19}$ The European Diabetes Forum (EUDF) has been launched as a follow-on from the 1989 initiative to address the landscape of diabetes care in Europe and influence policy. ${ }^{20}$ The Parliamentarians for Diabetes Global Network continues to champion the cause of diabetes across the political spectrum and EUDF should further support diabetes policy development at government level. ${ }^{21}$ 


\section{Forward planning}

From 16 to 19 September the Fira de Barcelona, Av. Joan Carles I (about 10 km from the airport and $8 \mathrm{~km}$ from La Rambla) is the venue for EASD 2019. September is an optimal month to visit Barcelona with temperatures ranging from $19^{\circ} \mathrm{C}$ to $27^{\circ} \mathrm{C}-$ so an opportunity to top up vitamin $\mathrm{D}$ reserves.

\section{References}

1. EASD Virtual Meeting Site. https://www. easd.org/virtualmeeting/home.html

2. 54th EASD Annual Meeting of the European Association for the Study of Diabetes, Berlin, Germany, 1-5 October 2018. Diabetologia 2018;61(Suppl 1):1-620. https://doi.org/10.1007/s00125-018-4693-0

3. EASD. Programme at a glance - 54th EASD Annual Meeting. https://www.easd.org/programme-2018.html

4. EASD 2018 - Industry programme. https://www.easd-industry.com/

5. SGLT2 inhibitors. Diabetologia. Special Issue, October 2018;61:65pp. http://diabetologiajournal.org/collections/sglt2-inhibitors/

6. Rosenstock J, Marquard J, Laffel LM, et al. Empagliflozin as adjunctive to insulin therapy in type 1 diabetes: the EASE trials. Diabetes Care 2018 Oct 4. pii: dc181749 [Epub ahead of print]. https://doi.org/10.2337/dc18-1749 http://care.diabetesjournals.org/content/early/2 018/10/03/dc18-1749.long

7. Danne T, Cariou B, Banks P, et al. $\mathrm{HbA}_{1 c}$ and hypoglycemia reductions at 24 and 52 weeks with sotagliflozin in combination with insulin in adults with type 1 diabetes: The European inTandem2 Study. Diabetes Care 2018;41: 1981-90. doi: https://doi.org/10.2337/dc18-034

8. Neuen BL, Ohkuma T, Neal B, et al. Cardiovascular and renal outcomes with canagliflozin according to baseline kidney function. Data from the CANVAS Program. Circulation 2018;138: 1537-50. https://doi.org/10.1161/CIRCULATIONAHA. 1
9. Ryan PB, Buse JB, Schuemie MJ, et al. Comparative effectiveness of canagliflozin, SGLT2 inhibitors and non-SGLT2 inhibitors on the risk of hospitalization for heart failure and amputation in patients with type 2 diabetes mellitus: a realworld meta-analysis of 4 observational databases (OBSERVE-4D). Diabetes Obes Metab 2018;20: 2585-97. https://doi.org/10.1111/dom.13424

10. Hernandez AF, Green JB, Janmohamed $S$, et al for the Harmony Outcomes Committees and Investigators. Albiglutide and cardiovascular outcomes in patients with type 2 diabetes and cardiovascular disease (Harmony Outcomes): a double-blind, randomised placebo-controlled trial. Lancet 2018;392:1519-29. http://dx.doi.org/ 10.1016/S0140-6736(18)32261-X

11. Muskiet MHA, Tonneijck L, Huang $Y$, et al. Lixisenatide and renal outcomes in patients with type 2 diabetes and acute coronary syndrome: an exploratory analysis of the ELIXA randomised, placebo-controlled trial. Lancet Diabetes Endocrinol 2018;6:869-69. https://doi.org/10.1016/\$2213-8587(18)30268-7

12. Frias JP, Nauck MA, Van J, et al. Efficacy and safety of LY3298176, a novel dual GIP and GLP-1 receptor agonist, in patients with type 2 diabetes: a randomised, placebo-controlled and active comparator-controlled phase 2 trial. Lancet 2018 Oct 3. pii: S0140-6736(18)322608 [Epub ahead of print]. http://dx.doi.org/ 10.1016/S0140-6736(18)32260-8

13. Davies MJ, D'Alessio DA, Fradkin J, et al. Management of hyperglycaemia in type 2 diabetes, 2018. A consensus report by the American Diabetes Association (ADA) and the European Association for the Study of Diabetes (EASD). Diabetologia 2018;61:2461-98. https://doi.org/ 10.1007/s00125-018-4729-5 and Diabetes Care 2018 https://doi.org/10.2337/dci18-0033.

14. Bohula EA, Wiviott SD, McGuire DK, et al, for the CAMELLIA-TIMI 61 Steering Committee and Investigators. Cardiovascular safety of lorcaserin in overweight or obese patients. N Engl J Med 2018;379:1107-17. https://doi.org/10.1056/NEJMoa1808721.
15. Bohula EA, Scirica BM, Inzucchi SE, et al, for the CAMELLIA-TIMI 61 Steering Committee and Investigators. Effect of lorcaserin on prevention and remission of type 2 diabetes in overweight and obese patients (CAMELLIATIMI 61): a randomised, placebo-controlled trial. Lancet 2018 Oct 3. pii: S0140-6736(18) 32328-6 [Epub ahead of print]. https://doi.org/ 10.1016/S0140-6736(18)32328-6

16. The RISE Consortium. Impact of insulin and metformin versus metformin alone on $\beta$-cell function in youth with impaired glucose tolerance or recently diagnosed type 2 diabetes. Diabetes Care 2018;41:1717-25. https://doi.org/10.2337/dc18-0787

17. Xiang AH, Trigo E, Martinez $M$, et al, for the RISE Consortium. Impact of gastric banding versus metformin on $\beta$-cell function in adults with impaired glucose tolerance or mild type 2 diabetes. Diabetes Care 2018 Oct; dc181662. https://doi.org/10.2337/dc18-1662

18. Tauschmann M, Thabit $H$, Bally $L$, et al, on behalf of the APCam11 Consortium. Closedloop insulin delivery in suboptimally controlled type 1 diabetes: a multicentre, 12-week randomised trial. Lancet 2018;392:1321-9. https:// doi.org/10.1016/S0140-6736(18)31947-0

19. Felton A-M, Hall MS. Diabetes - from St Vincent to Glasgow. Have we progressed in 20 years? Br J Diabetes Vasc Dis 2009;9:142-3. https://doi.org/10.1177/1474651409341318

20. EASD 2018-EUDF launch event. YouTube. https://www.youtube.com/watch?v=HsWtJ3K Rdeo

21. Sanders AM. The Melbourne Declaration on diabetes. Br J Diabetes Vasc Dis 2014;14:357. http://dx.doi.org/10.15277/bjdvd.2014.007

Correspondence: Dr Caroline Day, Visiting Fellow, Diabetes Group, Aston University, Birmingham B4 7ET, UK E-mail: cday@mededuk.com

http://dx.doi.org/10.15277/bjd.2018.199 Br J Diabetes 2018;18:180-182 